Marketing and Branding Research

WWW.CIKD.CA

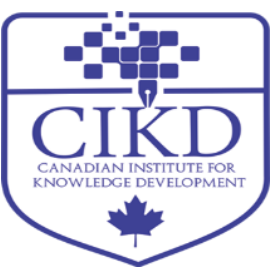

\title{
Crude Oil Price, Interest Rate and Unemployment Nexus in Nigeria: An Application of Toda and Yamamoto Long- Run Causality Procedure
}

\author{
Rabiu Maijama'a ${ }^{1^{*}}$, Kabiru Saidu Musa ${ }^{2}$ \\ ${ }^{1}$ Nigerian National Petroleum Corporation, Central Business District, Garki, Abuja-Nigeria \\ ${ }^{2}$ Department of Economics, Bauchi State University Gadau, Bauchi-Nigeria
}

Keywords:

Crude Oil Price, Interest Rate, Unemployment Rate, Augmented Dickey Fuller Unit Root Test, Breakpoint Unit Root Test, Toda and Yamamoto Granger Causality.

\section{Received}

22 December 2020

Received in revised form

28 December 2020

Accepted

29 December 2020

*Correspondence:

Rabiu.maijama'a@nnpcgroup.com

\begin{abstract}
This study aims to examine the relationship between crude oil price, interest rate and the unemployment rate in Nigeria using times series data for the 1991-2019 periods. The stationarity property of the series was examined using Augmented Dickey and Fuller (1979) and Elliot, Rothenberg and Stock's (1996) unit root test. The outcomes of Augmented Dickey and Fuller indicated a mixture of an order of integration among the series while Elliot et al.'s (1996) unit root test revealed that all the series are stationary at the first difference and therefore are said to integrate of order one. The Toda and Yamamoto long-run granger causality indicated that one-way causality exists flowing from crude oil price to unemployment rate, unemployment rate to interest rate, population growth to the unemployment rate, crude oil price to interest rate and population growth to interest rate alongside two-way causality flowing from population growth to crude oil price. Therefore, based on the empirical outcomes we recommended that labour will serve as an efficient substituting factor of production for energy and capital in the case of the Nigerian economy and Nigerian government should develop both industrial and noncrude oil sectors to create employment opportunities for the unemployed teeming population as well as increasing the country's export.
\end{abstract}

An important political and macroeconomic issue facing all economies is unemployment and due to the nature of its economic and social penalties, it becomes important for strategy makers to find those factors that are most accountable for the higher rate of unemployment. Again, it 
becomes necessary for the strategy makers to understand that unemployment dynamics and additional factors may vary between nations at varying economic development stages although developing nations have higher rates of unemployment than developed nations and also developing nations are characterized by higher rate of economic growth than developed nations (Doğrul \& Soytas, 2010).

The rates of unemployment have been growing in Nigeria, playing a key part in both the national and international economic policies. To show the trend of an increasing rate of unemployment in the country, Figure 2 present the graphical illustration of unemployment rate from 1991 to 2019 using the unemployment rate as a percentage of the country's total labour force modelled by the international labour organization. For instance, in 1991 the rate of unemployment was 3.6 percent of the total labour force. After ten years the rate of unemployment as a percent of the total country labour force was 3.8 percent which indicated that the trend is increasing. Again, from 2015, 2016, 2017, 2018 and 2019, the rates of unemployment were 4.31 percent, 7.06 percent, 8.39 percent, 8.24 percent and 8.10 percent of the total labour force of the country (World Development Indicators, 2020).

\section{UNEMPLOYMENT RATE}

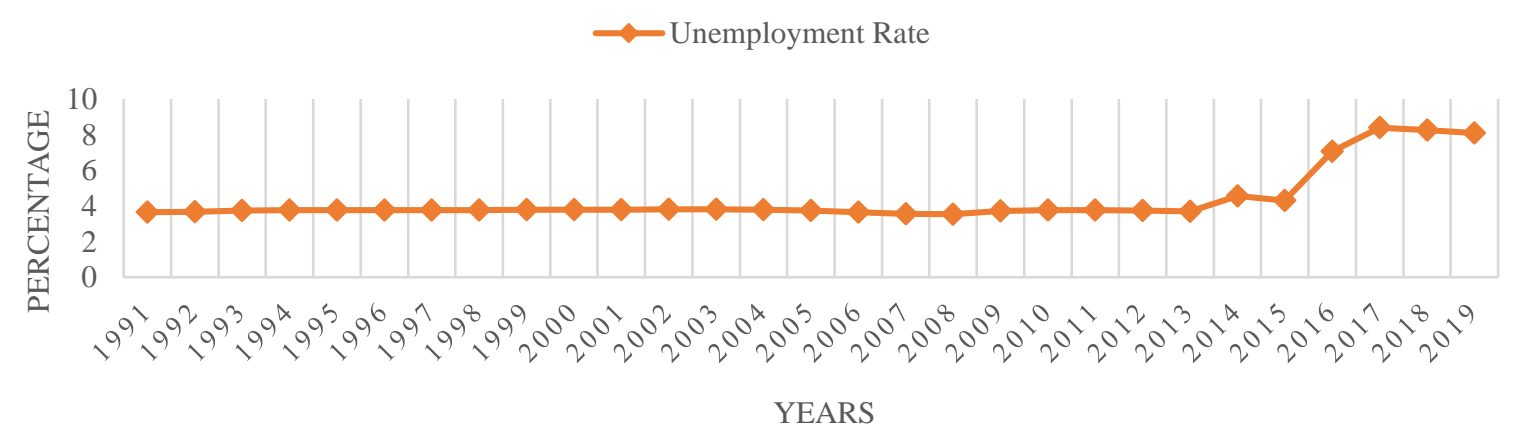

Figure 1. Unemployment rate (Source: Author's presentation using data from WDI, 2020).

Seeing unemployment from the framework of supply and demand, it can be maintained that the rate of unemployment largely depends on forces like labour productivity, labour wages, level of general price and the prices of additional factors of production. On a macroeconomic scale, the rate of unemployment will be encouraged by the national factors that include business cycle, the situation of the economy, level of technology, population changes and the international forces such as prices of energy. Therefore, for the country to formulate comprehensive macroeconomic agendas in the long run, the policymakers must understand the changes and microeconomic essentials via which the rate of unemployment is affected by some factors (Doğrul \& Soytas, 2010).

Some earlier studies drafted numerous channels of transmission via which fluctuations in crude oil price may possess some influence on the rate of economic activities (Adenikinju \& Omenka, 2013; Abraham, 2013; Alkhateeb, Mahmood, Sultan, \& Ahmad, 2017; Anand, Coady, Mohommad, Thakoor, \& Walsh 2013; Davis, 2013; Ezirim, Okeke, \& Ebiriga, 2010; Millington, 2016; Burakov, 2017; Siddig, Aguiar, Grethe, Minor, \& Walmmsley, 2014). The effect of classical supply-side emphasizes on the fact that increase in crude oil price is associated with the reduction in the level of output since a price increas is causing a reduction in the availability of basic production inputs and this leads to a decline in productivity as well 
as the growth rate. Gradually the declining growth in productivity will decrease growth in real wage and thereby causing a rise in the rate of unemployment (Brown \& Yücel, 2002; Doğrul \& Soytas, 2010).

Crude oil price fluctuations can cause an increase in the marginal production cost in various businesses and causing a decline in production thereby raising the rate of unemployment. Meanwhile, as the transfer of capital and specialized labour from a particular industry to another is expensive, workers do not transfer instantly but delay for the situations to improve and therefore causing a decline in total employment. After fluctuation in crude oil price, since the level of investment regulates the capacity of potential output in the long-run, higher prices of inputs triggered shocks in crude oil price diminish the level of investment, therefore, causing a decline in output (Brown \& Yücel, 2002; Doğrul \& Soytas, 2010). Figure 2 represents the graphical trend of crude oil price for the sample period of 1991 to 2019. The trend exhibit fluctuation and this shows how volatile price of crude oil is in the international energy market.

Crude Oil Price

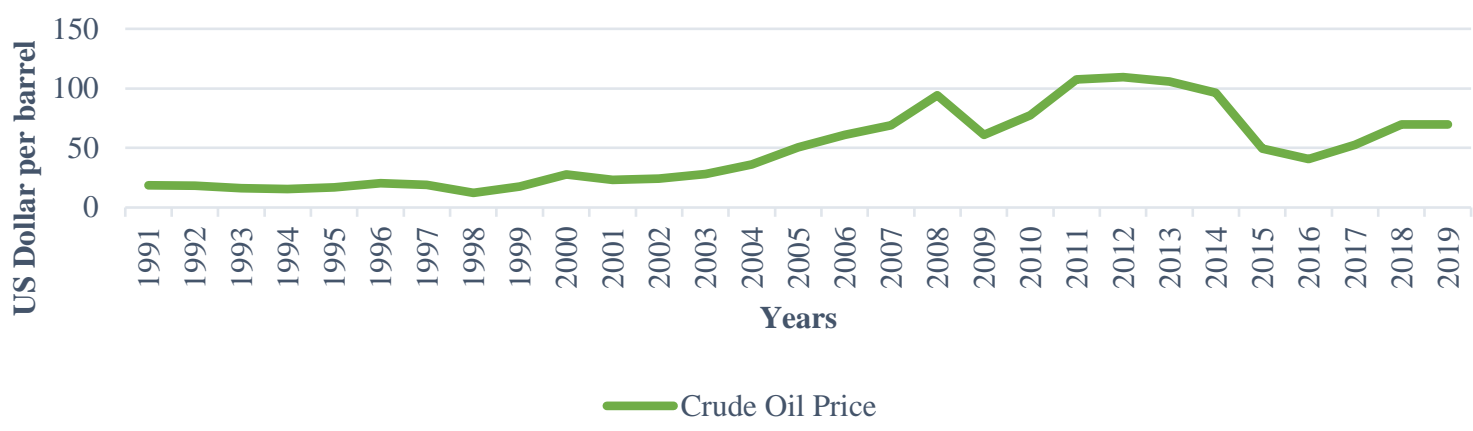

Figure 2. The trend of crude oil price (Source: Author's presentation using data from OPEC, 2020).

Rate of interest is the certain amount by which a borrower paid the lender for the usage of his asset or payment made by the bank regarding the saving certificates and this rate plays a vital role in the economy as it directly affects the behaviour of consumers which implies that savings and consumption are affected by the rate of interest (Mahmood, Rabia, \& Aslam, 2013). In the situation of higher rates of interest, consumers would try to save much of their income so that they can take advantage of higher returns rather than the end of in purchasing goods and services, therefore, high rates of interest are associated with the lower price level. Also, rate of interest may cause an increase or decrease in the unemployment rate as it affects the level of domestic investment and the ability to afford loans that can guarantee persons that are unemployed in the country to own and run their businesses (Mahmood et al., 2013).

Therefore, rates of interest have been considered as important elements for both formation and accumulation of capital and serve as the very vital in attracting Nigeria's output growth and due to the absolute underdevelopment of the local capital market and the scarcity of foreign direct investment inflow into the non-crude oil sector of the economy. Thus, for over the years, rate of interest itself has been anticipated to play a vital part in the determination of expansion rate or reduction of investment in the private sector and growth of output (Babalola, 2013).

Figure 3 shows the trend of lending interest rate in Nigeria for the sample period of 1991 to 2019 and the trend indicates that there is fluctuation in the rate of interest in the country which may increase or decrease the rate of unemployment in the country for the period under study. 
- Lending Interest Rate

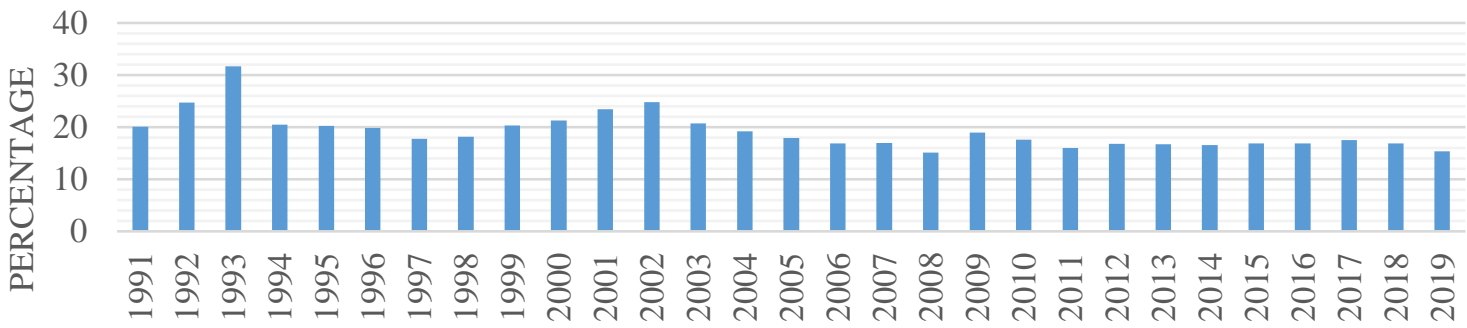

YEARS

Figure 3. trend of lending interest rate (Source: Author's presentation using data from WDI, 2020).

Figure 4 presents the relationship between crude oil price, interest rate, and the rate of unemployment in the case of the Nigerian economy for the sample period of 1991 to 2019. According to Figure 4, there is an increasing and positive relationship between crude oil price, interest rate and unemployment rate throughout the sample period even though there are some periods of fluctuations in the trend of the crude oil price.

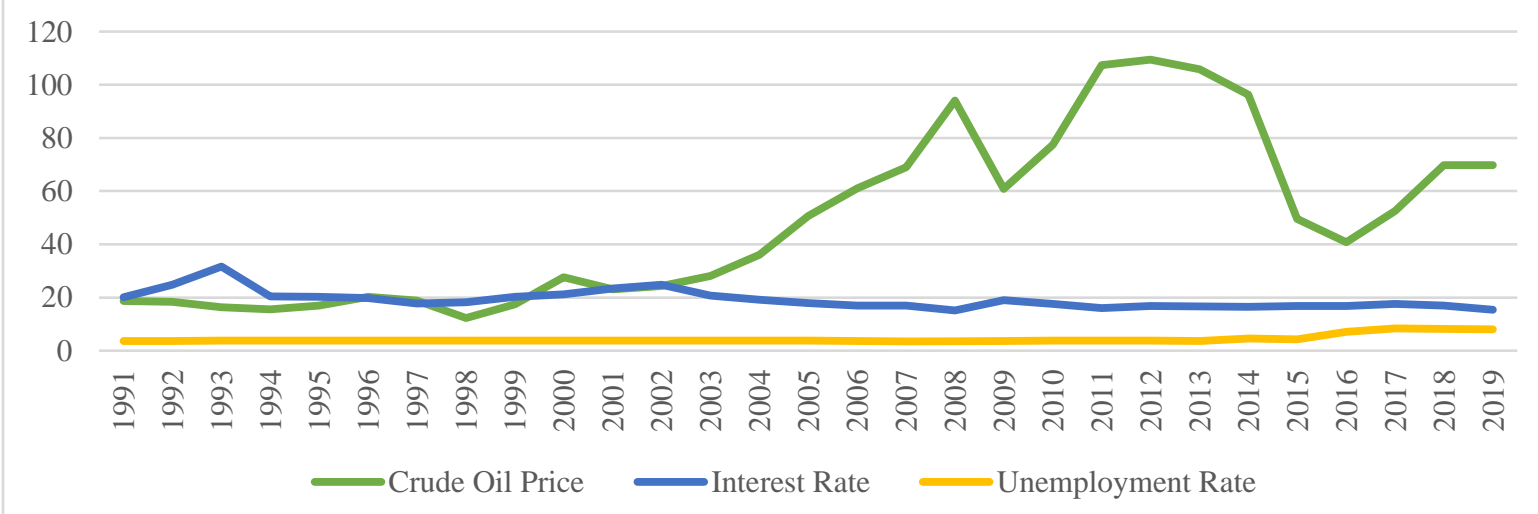

Figure 4. Crude oil price, interest rate and unemployment rate (Source: Authors' Presentation).

\section{Review of Literature}

The review of related literature is divided into two categories for easy identification of the research gap. The first category will present those studies done outside the research case study while the second category will present those studies carried out inside the research case study.

\section{Evidence from Foreign Studies}

Arshad and Ali (2016) investigated the impact of interest and inflation rates on unemployment rate in Pakistan for the sample 1974-2013 periods and applied ARDL bound test VECM approach to achieve the main objective. The results indicated that there is no significant relationship between the inflation rate and unemployment but a significant relationship exists between interest, inflation and unemployment rates in the short run. Population growth and exchange rate exert negative while external debt exerts a significant positive impact on the rate of unemployment. Money supply contributes to inflation whereas exchange rate and imports have a negative influence on inflation. Rate of interest and credit to the private sector are positively related but negatively related to the exchange rate. Muhdin (2016) in their study for 
the underlying problems of unemployment in the case of Ethopian economy applied descriptive statistic as a method of data analysis to analyze the data for the year 2015 on the total number of 16984 respondents. The results indicated that unemployment highly correlated factors are regional location, sex distribution, marital status and level of education. Joo and Sung (2017) investigated the influence of volatility in crude oil price on the stock returns of USA, Korea, Japan, and Hong Kong within the sample period of 1996 to 2015 through the model specification of VAR-DCC-BGARCG-in-Mean; their outcomes revealed that volatility in crude oil price has a negative and significant impact on the returns of the selected countries stock markets.

Alzyoud, Wang and Basso (2018) studied the influence of crude oil price on both the rate of exchange and returns of the stock market in the case of the Canadian economy for the sample period of 1986 to 2015 and applied regression analysis to realize the main objective. The outcomes revealed that the variables are not cointegrated and that fluctuations in both crude oil price and the rate of exchange have a significant positive effect on the stock returns of the Canadian stock market. Muthalib, Adam, Rostin, Saenong and Suriadi (2018) applied ARDL bounds test for cointegration in their examination for the effect of oil price and the rate of unemployment on poverty in Indonesia for the 1998-2017 periods. Their outcome revealed that oil price possessed negative and significant impact on the level of poverty in the short run but in the long run the rate of unemployment exerts a significant positive impact on the level of poverty in the country. Haque and Khan (2019) studied the impact of crude oil price and government expenditure on improving the standard of living from 1990 to 2016 in Saudi Arabia. Their result indicated that both crude oil exports and public spending are the significant drivers of the standard of living in the country in terms of human development index and that expenditure on education is the most significant factor. There was also a negative relationship between expenditure on health and economic growth of Saudi Arabia.

Akhmad, Romadhoni, Karim, Tajibu, and Syukur (2019) examined the influence of crude oil price on variations in economic growth, inflation rate and level of poverty in the case of the Indonesian economy for the period of 1980 to 2017 and utilized VAR model to realize the objective. The result revealed that crude oil price exerts a negative effect on the economy of Indonesia. Saidi, Aedy, Saranani, osnawintang, Adam and Sani (2020) in their examination for the asymmetric influence of crude oil price and fluctuations on the rate of exchange for the 2006-2017 periods through the application of non-linear ARDL indicated the asymmetric influence of crude oil price and fluctuation on the rate of exchange is in the short run while the long-run influence ceased to exist. Sapuan and Roly (2020) studied the influence of crude oil abundance on human capital in the case of the Malaysian economy considering the sample period of 1980 to 2017. The authors applied ARDL bounds approach for cointegration to realize the effect of the abundance of crude oil price on human capital and their result indicated that cointegration exists among the variables with a mixed result between exports of fuel, oilgas rent and human capital development.

In analyzing the asymmetric influence of crude oil price on the economic growth for the period of 1945 to 2018 in the case of the economy of Spain, Cantavella (2020) utilized nonlinear ARDL approach and the outcome indicated that decrease in the price of crude oil exerts a larger impact on the economic growth of the country than the increase in the price of crude oil. Kyari (2020) in his investigation for the appropriateness of petroleum tax incentives 
package in bringing the inflows of foreign direct investments into Nigeria used a questionnaire based on the five-point Likert scale and analyzed the data via descriptive statistics and the technique of Kruskal-Wallis. The outcome revealed that the package of petroleum tax incentive is adequate in number and suitable in attracting the inflows of foreign direct investment into the country. Rumbia et al. (2020) investigated the asymmetric short-run and long-run effect of crude oil prices on the economic growth of Indonesia and also determined how household expenditure affects the level of economic growth in the case of ASEAN-4 region for the period of 1967 to 2018. The data was analyzed using panel non-linear ARDL approach and the outcome indicated that the asymmetric effect of crude oil price on economic growth and economic growth is not affected by household expenditure in the long-run. In the short-run asymmetric effect of crude oil price on economic growth is reported and household expenditure influence economic growth.

Gylych, Jbrin, Celik and Isik (2020) applied the technique of Toda and Yamamoto long-run Granger causality to determine the influence of fluctuations in crude oil price on the instruments of monetary policy in Nigeria for the sample period of 1995 to 2018. The result indicated that there is a one-way causality running from interest rate to variations in crude oil price and exchange rate to variations in crude oil price. Impulse response function revealed a negative relationship of crude oil price with interest rate and positive relationship with inflation and exchange rate. Majidli and Guliyev (2020) studied the relationship between non-crude oil economic growth, exchange rate and crude oil price for the period ranging from 2005 to 2019. The data for the sample period was analyzed using FMOLS and the outcome indicated that crude oil price exerts a positive effect on real non-crude oil price economic growth while the rate of exchange exerts a negative impact on non-crude oil price economic growth. Wiryono, Sudrajad, Prasetio, and Setiawati (2020) investigated the influence of fluctuations in crude oil price on profitability, financial liquidity and financial leverage using the sample of ninety-four manufacturing companies for the 2000-2017 periods. The outcomes indicated consistency in the case of profitability, financial liquidity and financial leverage. Indonesia manufacturing companies' financial liquidity was not affected by crude oil prices.

\section{Evidence from Nigerian Studies}

Adenomon, Okoro-Ugochukwu and Adenomon (2018) applied fully modified ordinary least squares and error correction model tostudy the main determinants of unemployment in the case of the Nigerian economy for the sample period covering 1981 to 2016. The result from FMOLS revealed that exchange rate and population growth have signed positively with unemployment rate but interest rate has exerted a negative impact on the unemployment rate. Musa, Maijama'a, Nasiru and Sambo (2019) studied the effect of interest rate on inflation rate in the case of the Nigerian economy for the spanning 1970 to 2016 and applied ARDL bound approach to cointegration. The result indicated that the interest rate is positively related to inflation in both long-short run periods. The empirical finding of their study is in line with the argument of supporters of fiscal policy and contract the argument of supporters of monetary policy.

Maijama'a, Musa, Muktari and Mohammed (2019) studied the influence of population growth on the rate of unemployment in Nigeria for the period covering 1991-2017. The timeseries data for the study were analyzed using dynamic ordinary least squares and the outcome 
revealed that population growth and the rate of exchange have a positive sign with unemployment whereas foreign direct investment, per capita economic growth and consumer price index have a significant negative influence on the rate of unemployment in the long-run period. Bala, Ibrahim and Hadith (2020) explored the influence of population growth, unemployment and poverty on the economic growth of Nigeria for the period of 1980 to 2017 and utilized the ARDL bound approach for cointegration. The result revealed that there is cointegration relationship among the interest variables and that foreign direct investment and population growth exerts a significant positive effect on economic growth whereas poverty and unemployment have a significant negative impact on the economic growth of the country. Musa, Maijama'a, Shaibu and Muhammad (2019) investigated the impact of crude oil price and exchange rate on economic growth in Nigeria by employing ARDL approach to analyze the time series data spanning of 1982-2018. The outcome indicates that the crude oil price and exchange rate have a positive and significant impact on economic growth in the long run and short-run periods. The finding suggested that the crude oil price and the exchange rate could affect economic growth in the two periods.

Maijama'a and Musa (2020) studied the impact of oil price, urbanization on the level of environmental pollution considering the Nigerian economy as a case study for the period of 1981 to 2016 and applied ARDL approach to cointegration. The outcome indicated that there is cointegration relationship among the variables and that long-short run results revealed that crude oil price and foreign direct investment have a significant negative impact on the level of environmental pollution in the country whereas urbanization has a significant positive impact on the country's environmental pollution. Ehikioya et al. (2020) considered the case of selected sub-Saharan African nations for the sample period of 2004 to 2017 and applied VECM approach to study the relationship between fluctuations in crude oil price and the real rate of exchange movement. The outcomes revealed the existence of cointegration relationship among the interest series and crude oil prices aid in forecasting real exchange movement in the case of Angola, Equatorial Guinea, Gabon, Nigeria and the Republic of Congo. Maijama'a and Musa (2020) applied vector error correction model and granger causality to study the effect of crude oil price fluctuations on unemployment rate in the case of the Nigerian economy for the period spanning 1991-2018. The results of the study indicated that population and economic growths have a significant positive impact on the unemployment rate whereas the price of crude oil and consumption of electricity exerts a significant negative impact on unemployment in the long-run. But in the short-run, only population growth has a significant positive impact on unemployment. The granger causality results indicated that unidirectional causality flows between population growth and unemployment, economic growth and unemployment, crude oil price and unemployment, population growth and economic growth, crude oil price and population growth, crude oil price and economic growth, electricity consumption and economic growth.

In another development from the same case of study, Musa and Maijama'a (2020) studied the relationship between consumption of renewable energy and unemployment for the period of 1991 to 2015 and utilized the T-Y procedure to determine the objective. The outcome indicated that there is a two-way causality flowing from energy consumption to unemployment, foreign direct investment to renewable energy consumption, investments to renewable energy consumption, credit to the private sector to renewable energy consumption, foreign direct 
investments to investments, credit to the private sector to investments alongside one-way causality flowing between investments and unemployment, credit to the private sector to unemployment. Oduyemi and Owoeye (2020) explored on how variations in the price of crude oil influence the health outcomes in the case of the Nigerian economy. The data for the study ranges from 1980 to 2017 and it was analyzed using the VAR model. The outcomes of the investigation indicated that fluctuations in crude oil price do not have a harmful effect on the health outcomes in the country which means that fluctuations in the crude oil price are neither compulsory nor adequate in explaining variations in health outcomes in the country. Musa, Maijama'a, Mohammed and Usman (2020) studied the impact of oil price on exchange rate using time series data from 1983 to 2017 in Nigeria. Using the ARDL approach to analyze the data, the result revealed that oil price has a negative and significant impact on the exchange rate in both the short run and long run. Whereas oil revenue and gross domestic products have a significant positive impact on the exchange rate. The finding suggested that the oil price could affect the exchange rate in both the short run and long run.

\section{Method}

\section{Data Structures and the Empirical Model}

In this research, based on the empirical model of Doğrul and Soytas (2010), our main objective is to investigate the dynamic association between crude oil price, interest rate and unemployment in the case of the Nigerian economy for the sample period of 1991 to 2018 . In realizing the main objective, we engaged the long-run granger causality test known as Toda and Yamamoto procedure (Toda \& Yamamoto, 1995). Since differenced terms are absent regarding this procedure in any of the Equations and the literature, the outcomes from this procedureare called the long-run Granger causality. Therefore, to determine the connection between crude oil price, interest rate and unemployment rate, we utilized the yearly data spanning 1991 to 2018 respectively. The data on unemployment $\left(U_{E M}\right)$, interest rate $\left(\operatorname{INR}_{t}\right)$ and population growth $\left(\mathrm{POG}_{\mathrm{t}}\right)$ were extracted from the World Development Indicators (2020) while data on crude oil price $\left(\mathrm{COP}_{\mathrm{t}}\right)$ was sourced from the OPEC's database. The unemployment rate is measured by the total unemployment (percentage of the total labor force, modeled ILO estimate), the interest rate is measured by lending interest rate expressed in percentage, population growth is measured as population growth expressed in annual percentage and crude oil price is measured in U.S. dollar per barrel crude oil market price. All the data on these four variables were converted to their natural logarithmic forms.

Toda and Yamamoto test for the long-run Granger causality is applicable to variables that have mixed order of integration and unlike the procedure of Johansen-Juselius, it does not require pre-testing for cointegration relationship among the interest series. The technique of Toda and Yamamoto only necessitates the knowledge of the maximum integration order of the interest variables and to determine the variables' stationarity properties, we have employed 3 different unit root tests of augmented Dickey and Fuller (1979), Elliot et al. (1996) and Breakpoint unit root. The outcomes of these unit root tests are presented in Table 2 and 3 respectively. Based on the unit root outcomes given in Table 2 and 3, even though there are a few inconsistent outcomes, we can safely consider I(1) to be the maximum order of integration $(d=1)$. Since the maximum order of integration among our series is $I(1)$, then we continue with the Toda and Yamamoto procedure. The procedure includes a vector autoregressive (VAR) in 
level forms; therefore, there will not be a loss of information because of differences. By conducting a Wald test on the 1st $\mathrm{k}$ values of augmented VAR $(\mathrm{k}+\mathrm{d})$ model and the numeral follows an asymptotic Chi-square distribution with $\mathrm{k}$ degrees of freedom $\left(\chi^{2}(\mathrm{k})\right.$. In this research, 4 is the optimum lag length $\mathrm{k}$ as determined by the likelihood ratio test (LR), final prediction error (FPE), Akaike information criteria (AIC), Schwarz information criteria (SIC), and Hannan-Quinn information criterion (HQ) respectively. Thus, the lag length became 5 $(\mathrm{K}+\mathrm{d}=5)$ when we augmented the VAR with the series' maximum order of and the estimated VAR (5) system of Equation as presented from Equation 1 to 4 below:

$$
\begin{aligned}
\ln U E M_{t}=\theta_{0} & +\sum_{i=1}^{k} \chi_{1 i} \ln U E M_{t-i}+\sum_{p=k+1}^{d_{\text {max }}} \chi_{2 p} \ln U E M_{t-p}+\sum_{i=1}^{k} \beta_{1 i} \ln I N R_{t-i}+\sum_{p=k+1}^{d_{\text {max }}} \beta_{2 p} \ln I N R_{t-p} \\
& +\sum_{i=1}^{k} \partial_{1 i} \ln C O P_{t-i}+\sum_{p=k+1}^{d_{\max }} \partial_{2 p} \ln C O P_{t-p}+\sum_{i=1}^{k} \delta_{1 i} \ln P O G_{t-i}+\sum_{p=k+1}^{d_{\max }} \delta_{2 p} \ln P O G_{t-p}+\varpi_{1 t}
\end{aligned}
$$

$$
\begin{aligned}
\ln I N R_{t}=\varphi_{0} & +\sum_{i=1}^{k} \vartheta_{1 i} \ln I N R_{t-i}+\sum_{p=k+1}^{d_{\max }} \vartheta_{2 p} \ln I N R_{t-p}+\sum_{i=1}^{k} \alpha_{1 i} \ln U E M_{t-i}+\sum_{p=k+1}^{d_{\max }} \alpha_{2 p} \ln U E M_{t-p} \\
& +\sum_{i=1}^{k} \phi_{1 i} \ln C O P_{t-i}+\sum_{p=k+1}^{d_{\max }} \phi_{2 p} \ln C O P_{t-p}+\sum_{i=1}^{k} \gamma_{1 i} \ln P O G_{t-i}+\sum_{p=k+1}^{d_{\max }} \gamma_{2 p} \ln P O G_{t-p}+\varpi_{2 t}
\end{aligned}
$$

$$
\begin{aligned}
\ln C O P_{t}=\eta_{0} & +\sum_{i=1}^{k} \lambda_{1 i} \ln C O P_{t-i}+\sum_{p=k+1}^{d_{\max }} \lambda_{2 p} \ln C O P_{t-p}+\sum_{i=1}^{k} \pi_{1 i} \ln U E M_{t-i}+\sum_{p=k+1}^{d_{\max }} \pi_{2 p} \ln U E M_{t-p} \\
& +\sum_{i=1}^{k} \xi_{1 i} \ln I N R_{t-i}+\sum_{p=k+1}^{d_{\max }} \xi_{2 p} \ln I N R_{t-p}+\sum_{i=1}^{k} \delta_{1 i} \ln P O G_{t-i}+\sum_{p=k+1}^{d_{\max }} \delta_{2 p} \ln P O G_{t-p}+\varpi_{3 t}
\end{aligned}
$$

$$
\begin{aligned}
\ln P O G_{t}=\sigma_{0} & +\sum_{i=1}^{k} v_{1 i} \ln P O G_{t-i}+\sum_{p=k+1}^{d_{\max }} v_{2 p} \ln P O G_{t-p}+\sum_{i=1}^{k} \psi_{1 i} \ln U E M_{t-i}+\sum_{p=k+1}^{d_{\max }} \psi_{2 p} \ln U E M_{t-p} \\
& +\sum_{i=1}^{k} \tau_{1 i} \ln I N R_{t-i}+\sum_{p=k+1}^{d_{\max }} \tau_{2 p} \ln I N R_{t-p}+\sum_{i=1}^{k} \omega_{1 i} \ln C O P_{t-i}+\sum_{p=k+1}^{d_{\max }} \omega_{2 p} \ln C O P_{t-p}+\varpi_{4 t}
\end{aligned}
$$

Where $\ln \mathrm{UEM}_{\mathrm{t}}, \ln \mathrm{lNR}_{\mathrm{t}}, \operatorname{lnCOP}_{\mathrm{t}}$, and $\ln \mathrm{POG}_{\mathrm{t}}$, are the natural logarithms of the unemployment rate, interest rate, crude oil price, and population growth, the optimal lag order is denoted by $\mathrm{k}$, variables maximum order of integration is given by $\mathrm{d}$ and $\varpi_{1 \mathrm{t}} \ldots \varpi_{4 \mathrm{t}}$ are the white noise terms.

\section{Result}

\section{Empirical Findings and Discussion}

This section presents the outcomes of the empirical investigation between crude oil price, interest rate and the rate of unemployment in Nigeria. The empirical investigation has kicked off with the variable graphical presentation for trend identification in the series. Graphs in Figure 5 has documented the bar presentation of all four series. It can be observed that population growth attends the highest peak in the year 2012 and began to fall in the year 2013 up to 2018. The trend of the unemployment rate was relatively stable from 1992 up to around 
2013 and from 2014 up to 2018, there was an increasing trend. The trends of crude oil price and interest rate were fluctuating from the starting period up to the ending period and these show how volatile crude oil price and interest rate are.
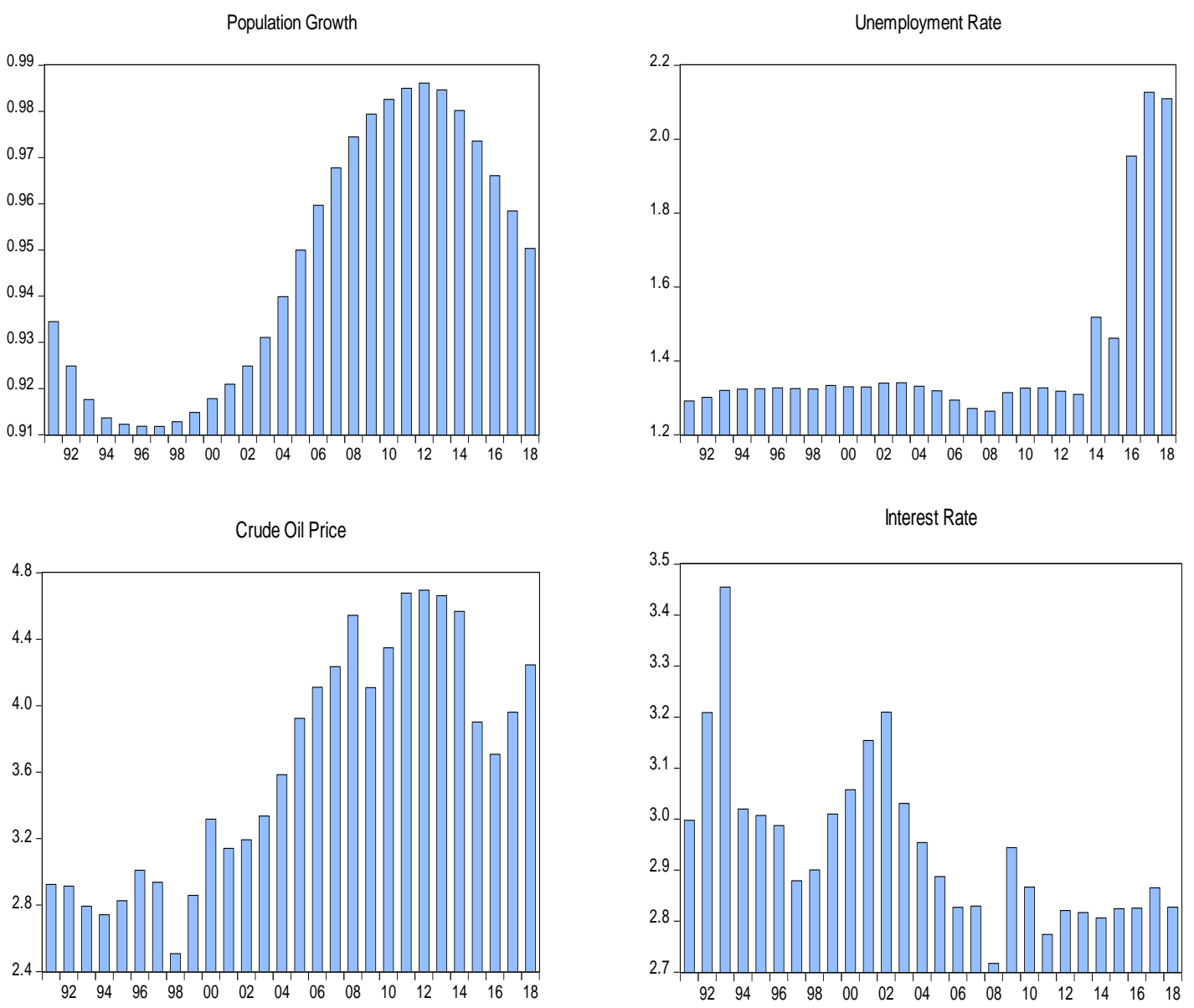

Figure 5. Population growth, unemployment rate, crude oil price and interest rate.

After identifying the nature of each of the series and presented in form of the graph as offered above, here comes to a variables' descriptive statistic and correlation analysis and the outcomes were presented in Table 1 and 2 respectively. The descriptive statistic reported in Table 1 and the areas of description include the mean, the minimum and maximum values the standard deviation, the skewness; kurtosis, and Jarque-Bera. The correlation analysis indicates that there is a positive correlation between unemployment and population growth; population growth and crude oil price; unemployment and crude oil price alongside negative correlation between unemployment and interest rate; population growth and interest rate; interest rate and crude oil price. More importantly, the correlation values were within the benchmark of .801.00 which indicates that there is no problem of multicollinearity among our interest series (Pordan, 2013). 
Table 1

Descriptive Statistics and Correlation Analysis

\begin{tabular}{lcccc}
\hline & $\mathrm{UEM}_{\mathrm{t}}$ & $\mathrm{POG}_{\mathrm{t}}$ & $\mathrm{INR}_{\mathrm{t}}$ & $\mathrm{COP}_{\mathrm{t}}$ \\
\hline Mean & 4.22 & 2.57 & 19.30 & 47.80 \\
Maximum & 8.38 & 2.68 & 31.65 & 109.45 \\
Minimum & 3.53 & 2.48 & 15.13 & 12.28 \\
Std. Dev. & 1.32 & 0.07 & 3.48 & 32.22 \\
Skewness & 2.54 & 0.14 & 1.81 & 0.67 \\
Kurtosis & 7.80 & 1.42 & 6.77 & 2.10 \\
Jarque-Bera & $57.07^{* * *}$ & 3.00 & $32.11^{* * *}$ & 3.05 \\
Observations & 28 & 28 & 28 & 28 \\
lnUEM & 1.00 & 0.17 & -0.24 & 0.19 \\
lnPOG & & 1.00 & -0.67 & 0.94 \\
lnINR & & & 1.00 & -0.69 \\
$\ln _{* * *}$ & & & & 1.00 \\
\hline
\end{tabular}

**** Indicates significance at $1 \%$

The unit root test results from both ADF and ERS were reported in Table 2. The outcomes from the ADF test indicated that $\ln \mathrm{UEM}_{t}, \operatorname{lnINR}_{\mathrm{t}}$ and $\operatorname{lnCOP} \mathrm{P}_{\mathrm{t}}$, were not statistically significant at the level because their p-values were greater than .05 but became statistically significant after 1 st differencing as their $\mathrm{p}$-values were less .05 and these variables are said to be integrated of order one or I(1) while $\operatorname{lnPOG}_{\mathrm{t}}$ variable appears to be significant at the level form and it is said to be $\mathrm{I}(0)$. Whereas, under the ERS unit root test, it appears that all the series were stationary at level forms since their test statistics were greater than the asymptotic critical values at different levels of significances. In summary, both ADF and ERS unit root tests revealed that the highest order of integration is I(1) and therefore, we can safely assume that the maximum integration order of our variables to be used in Toda and Yamamoto procedure is $1(\mathrm{~d}=1)$.

Table 2

Unit Root Test Results

\begin{tabular}{|c|c|c|c|c|}
\hline \multirow[b]{3}{*}{ Series } & \multicolumn{2}{|c|}{ Level } & \multicolumn{2}{|c|}{ 1st Difference } \\
\hline & \multicolumn{2}{|c|}{$\mathrm{ADF}$} & \multicolumn{2}{|c|}{ ERS } \\
\hline & Intercept & Intercept \& Trend & Intercept & Intercept \& Trend \\
\hline \multirow[t]{2}{*}{$\operatorname{lnUEM_{t}}$} & 0.89 & -0.10 & $1563.13^{* * * *}$ & $375.62^{* * *}$ \\
\hline & $(0.99)$ & $(0.99)$ & [1.87] & {$[4.22]$} \\
\hline \multirow[t]{2}{*}{$\operatorname{lnINR}_{t}$} & -2.17 & $-3.46^{*}$ & $3.37^{* * *}$ & $8.29^{* * * *}$ \\
\hline & $(0.21)$ & $(0.06)$ & {$[1.87]$} & {$[4.22]$} \\
\hline \multirow[t]{2}{*}{$\operatorname{lnCOP}_{t}$} & -1.03 & -1.76 & $18.31^{* * * *}$ & $15.74^{* * *}$ \\
\hline & $(0.72)$ & $(0.69)$ & {$[1.87]$} & {$[4.22]$} \\
\hline \multirow[t]{2}{*}{$\operatorname{lnPOG}_{\mathrm{t}}$} & $-4.82^{* * * *}$ & $-3.25^{*}$ & $6.19^{* * *}$ & $10.82^{* * * *}$ \\
\hline & $(0.00)$ & $(0.09)$ & {$[1.87]$} & [4.22] \\
\hline \multirow[t]{2}{*}{$\Delta \operatorname{lnUEM}_{\mathrm{t}}$} & $-4.62^{* * * *}$ & $-5.31^{* * * *}$ & $960.98^{* * *}$ & $75209.90^{* * *}$ \\
\hline & $(0.00)$ & $(0.00)$ & [1.87] & [4.22] \\
\hline \multirow[t]{2}{*}{$\Delta \operatorname{lnINR} R_{t}$} & $-5.94^{* * *}$ & $-5.83^{* * *}$ & $3.69^{* * *}$ & $8.61^{* * * *}$ \\
\hline & $(0.00)$ & $(0.00)$ & [1.87] & [4.22] \\
\hline \multirow[t]{2}{*}{$\Delta \operatorname{lnCOP}{ }_{t}$} & $-4.28^{* * * *}$ & $-4.23^{* *}$ & $1.96^{* * * *}$ & 3.31 \\
\hline & $(0.00)$ & $(0.01)$ & [1.87] & [4.22] \\
\hline \multirow[t]{2}{*}{$\Delta \ln \mathrm{POG}_{\mathrm{t}}$} & -1.40 & -0.48 & $2.14^{* * *}$ & $292.35^{* * *}$ \\
\hline & $(0.56)$ & $(0.97)$ & [1.87] & [4.22] \\
\hline
\end{tabular}

ERS stands for the Elliott-Rothenberg-Stock unit root test and values in [] are the asymptotic critical values; ${ }^{* * *}$ Indicates significance at $1 \%$, ${ }^{* *}$ Indicates significance at $5 \%,{ }^{*}$ Indicates significance at $10 \%$.

The results of unit root tests from ADF and ERS reported in Table 2 does not capture the existence structural breaks in the series and for that reason, we have employed the breakpoint unit root test to serve as the robustness check to the results of ADF and ERS root tests and to correct the problem of structural breaks in our series and the outcome is reported in Table 3. 
The outcome from the test indicated that $\ln \mathrm{UEM}_{\mathrm{t}}$ and $\operatorname{lnPOG}_{\mathrm{t}}$ are stationary at the level and they are said to be integrated of order zero or commonly presented as $I(0)$ while $\ln I N R_{t}$ and $\operatorname{lnCOP}_{\mathrm{t}}$ were not stationary at their level but after first differencing, they were able to attain stationarity level and they are said to be integrated of one or more commonly written as I(1). In a nutshell, the result from the breakpoint unit root test also supported I(1) as the maximum order of integration $(\mathrm{d}=1)$.

Table 3

Result of Breakpoint Unit Root Test

\begin{tabular}{lcccc}
\hline Series & Intercept & Break Date & Intercept \& Trend & Break Date \\
\hline $\operatorname{lnUEM}_{\mathrm{t}}$ & $-6.21^{* * *}(5)$ & 2008 & $-6.20^{* * *}(1)$ & 2014 \\
$\operatorname{lnINR}_{\mathrm{t}}$ & $-4.93^{* * *}(3)$ & 2006 & $-3.95(0)$ & 1997 \\
$\operatorname{lnCOP}_{\mathrm{t}}$ & $-3.11(0)$ & 2003 & $-3.32(1)$ & 2015 \\
$\operatorname{lnPOG}_{\mathrm{t}}$ & $-7.17^{* * *}(1)$ & 2017 & $-4.76^{* *}(4)$ & 1995 \\
$\Delta \operatorname{lnUEM}_{\mathrm{t}}$ & $-7.24^{* * *}(1)$ & 2015 & $-3.09(5)$ & 2006 \\
$\Delta \operatorname{lnINR}_{\mathrm{t}}$ & $-7.08^{* * *}(0)$ & 1994 & $-6.94^{* *}(0)$ & 1994 \\
$\Delta \operatorname{lnCOP}_{\mathrm{t}}$ & $-5.63^{* * *}(1)$ & 2014 & $-5.34^{* * *}(1)$ & 2006 \\
$\Delta \operatorname{lnPOG}_{\mathrm{t}}$ & $-2.67(1)$ & 2012 & $-6.05^{* * *}(1)$ & 2007 \\
\hline
\end{tabular}

Values in () are the lag length, ${ }^{* * *}$ Indicates significance at $1 \%,{ }^{* *}$ Indicates significance at $5 \%,{ }^{*}$ Indicates significance at $10 \%$

Given the outcome of VAR for the optimum lag selection in Table 4, the optimum lag selected by all the 5 criteria is lag 4 and in addition to the examination of the VAR stability, we have subjected our selected lag to a series of reliability tests that include serial correlation, heteroscedasticity, normality and stability problems respectively and their outcomes are reported in the lower part of Table 4 . The outcome of the examination revealed that the selected lag is free from the serial correlation problem and the errors in it are normally distributed but the test has failed to pass the heteroscedasticity problem because the p-value is less than .05 and there is no stability in the lag as indicated by the VAR stability graph because the one root is outside the unit circle. Therefore, these reliability results give us confidence in applying the Granger causality Wald test.

Table 4

Optimum Lag Selection Result

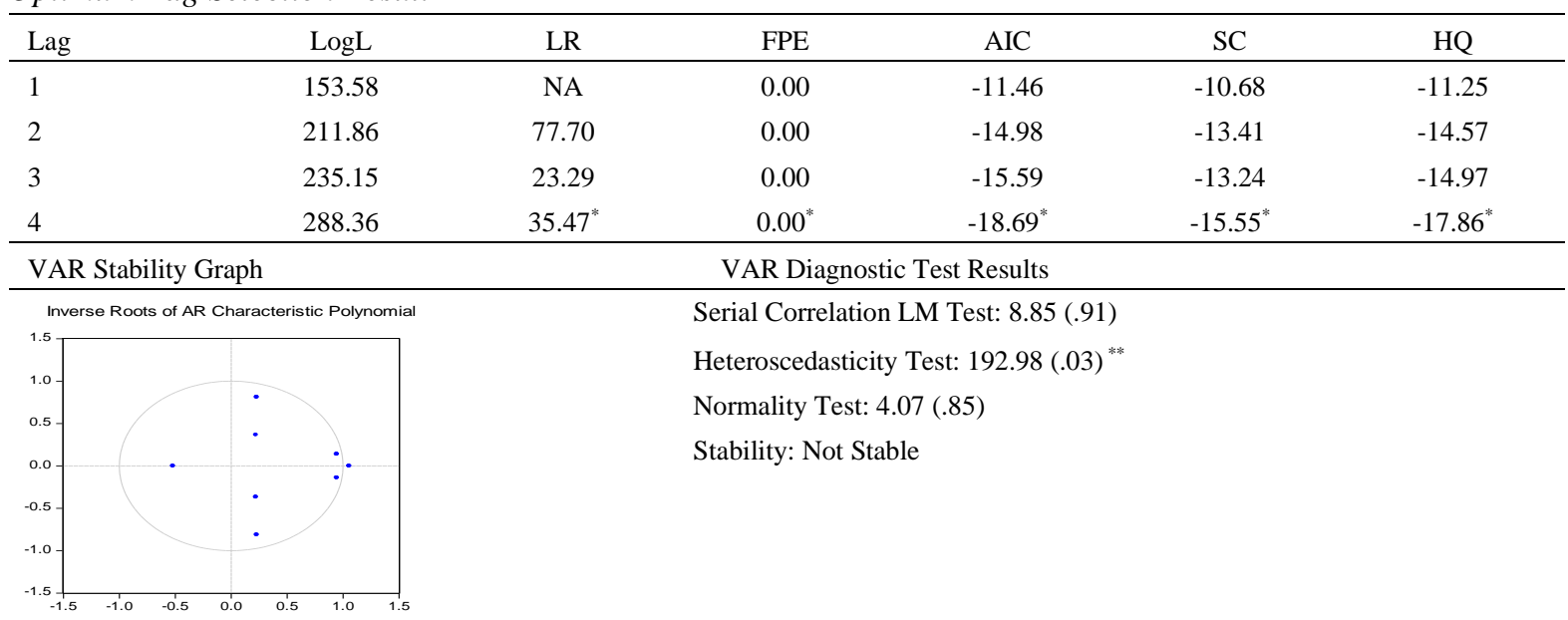

\footnotetext{
${ }^{*}$ Indicates selected lag length, ${ }^{* *}$ Indicates significance at $5 \%$.
} 
The framework of Granger causality allows for examining the existence plus the causality direction among our four variables. The procedure of Toda and Yamamoto permits us to determine the long-run causality tests without any need for cointegration testing and assessing the cointegration equation (Doğrul \& Soytas, 2010). The outcomes of the long-run causality based on Equation 1-4 given above for each variable, we have summarized the results in Table 6.

From the outcomes, we witness that there exist eight consecutive significant outcomes. Crude oil price granger causes unemployment and unemployment granger causes unemployment in the long run. Hence, crude oil price knowledge may improve the unemployment rate predictions and the reverse is the case; therefore, the causality between these variables is said to be bidirectional. The finding of positive connection between the price of energy and the rate of unemployment is inconsistent with that of researchers such as Papapetrou (2001) for Greece who reported unidirectional causality between crude oil price and employment and Doğrul and Soytas (2010) for emerging market who reported unidirectional causality between crude oil price and unemployment.

Unemployment rate granger causes interest rate but the interest rate does not; granger causes unemployment in the long run. Therefore, there is a one-way causality running from unemployment to interest rate. This finding is in line with that of Dogrul and Soytas (2010) for the emerging market study who reported independent directional causality between the unemployment rate and interest rate.

Again, population growth granger causes unemployment but the unemployment rate does not; granger causes population growth in the long run. Hence, there is a unidirectional causality running from population growth to the unemployment rate. This result corroborates the result of Maijama'a et al. (2019) who reported positive connection between population growth and the unemployment rate in Nigeria.

Similarly, crude oil price granger causes interest rate but the interest rate does not; granger causes unemployment rate in the long run. Hence, there is a one-way causality flowing from crude oil price to interest rate and this corroborates the finding of Doğrul and Soytas (2010) who reported independent causality between crude oil price and interest rate in the case of emerging market study. Moreover, population growth granger causes crude oil price and vice versa in the long run. Hence, the knowledge of crude oil price can be used to forecast the growth of the country's population and the causality between these series is said to be bidirectional. Furthermore, population growth granger causes interest rate but interest rate does not; granger causes population growth in the long run. Therefore, the causality between population growth and interest rate is not bidirectional. 
Table 6

Toda and Yamamoto Causality Outcome

\begin{tabular}{llcc}
\hline From & To & Test-statistic & P-values \\
\hline Crude Oil Price & Unemployment & $15.04^{* *}$ & 0.01 \\
Unemployment & Crude Oil Price & $12.10^{* *}$ & 7.38 \\
Interest Rate & Unemployment & $11.91^{* *}$ & 0.03 \\
Unemployment & Interest Rate & $37.24^{* * *}$ & 0.19 \\
Population Growth & Unemployment & 7.20 & 0.03 \\
Unemployment & Population Growth & $16.67^{* * *}$ & 0.00 \\
Crude Oil Price & Interest Rate & 5.26 & 0.20 \\
Interest Rate & Crude Oil Price & $33.58^{* * *}$ \\
Population Growth & Crude Oil Price & $12.14^{* *}$ \\
Crude Oil Price & Population Growth & 5.26 & 0.00 \\
Interest Rate & Population Growth & $25.94^{* * *}$ \\
Population Growth & Interest Rate & 0.38 \\
The test statistics follow a Chi-square distribution with 5 degrees of freedom, ${ }^{* *}$ Indicates significance at 5\%, ${ }^{* * *}$ Indicates significance at & 0.03 \\
$1 \%$. & & 0.38 \\
\end{tabular}

\section{Summary, Conclusion and Recommendation}

This paper examined the relationship between crude oil price, interest rate and the unemployment rate in the case of the Nigerian economy for the period of 1991 to 2019 to determine the order of integration of the variables. We have employed the Augmented Dickey and Fuller (1979) (ADF) and Elliot et al. (1996) (ERS) unit root tests results. The outcome from the ADF test indicates that unemployment rate, interest rate and crude oil price were not stationary at level but became stationary after first differencing while population growth appears to be stationary at level. But under the ERS unit root test, all the series were stationary at the level since the test statistics were greater than their asymptotic critical values. To tackle the problem of structural breaks in the series, we have employed the breakpoint unit root test to serve as the robustness check to the unit root tests of ADF and ERS. The outcome from the test indicates that the unemployment rate and population growth are stationary at the level while interest rate and crude oil price were stationary at first difference.

To determine the causality between the interest series, we have utilized the Toda and Yamamoto long-run causality and the result of the test indicated that crude oil price granger causes unemployment rate and unemployment rate granger to cause interest rate. Again, population growth granger causes unemployment rate. Similarly, crude oil price granger causes interest rate. Moreover, population growth granger causes crude oil price and vices versa. Furthermore, population growth granger causes the interest rate.

Through Toda and Yamamoto long-run causality, we were able to establish that crude oil price, interest rate and population growth affect the level of unemployment in Nigeria. Our findings suggested that in the long-run period crude oil price, interest rate and population growth affect the rate of unemployment in Nigeria, confirming Doğrul and Soytas's (2010) outcomes in the case of Turkey. Our outcomes recommended that labour will serve as an efficient substitute factor of production for energy and capital in the case of the Nigerian economy and that Nigerian government should develop both the industrial and non-crude oil sectors to create employment opportunities for unemployed teeming population and increase country's export. 


\section{References}

Abraham, T. W. (2013). Mitigating climate change in Nigeria: Fuel subsidy removal as a possible policy option. USAEE Working Paper, No. 13-105. Retrieved from http://ssrn.com/abstract=2205514.

Adenikinju, A., \& Omenka, S. (2013). Fuel subsidy removal in Nigeria: An analysis of dynamic general equilibrium effects. Nigerian Journal of Economic and Social Studies, 55(2), 6-25.

Adenomon, M. O., Okoro-Ugochukwu, N. A., \& Adenomon, C. A. (2018). On the determinants of unemployment rate in Nigeria: Evidence from fully modified OLS and error correction model. Preprints. https://doi.org/10.20944/preprints201812.0143.v1

Akhmad, Romadhoni, B., Karim, K., Tajibu, M. J., \& Syukur, M. (2019). The impact of fuel oil price fluctuations on Indonesia's macroeconomic condition. International Journal of Energy Economics and Policy, 9(2), $277-282$. https://doi.org/10.32479/ijeep.7470

Alkhateeb, T. T.Y., Mahmood, H., Sultan, Z. A., \& Ahmad, N. (2017). Oil price and employment nexus in Saudi Arabia. International Journal of Energy Economics and Policy, 7(3), 277-281.

Alkhateeb, T. T. Y., Sultan, Z. A., \& Mahmood, H. (2017). Oil revenue, public spending, gross domestic product and employment in Saudi Arabia. International Journal of Energy Economics and Policy, 7(6), 27-31.

Alzyoud, H., Wang, E. Z., \& Basso, M. G. (2018). Dynamics of Canadian oil price and its impact on exchange rate and stock market. International Journal of Energy Economics and Policy, 8(3), 107-114.

Anand, R., Coady, D., Mohommad, A., Thakoor, V., \& Walsh, J. P. (2013). The fiscal and welfare impacts of reforming fuel subsidies in India. IMF Working Paper, 128.

Arshad, S., \& Ali, A. (2016). Trade-off between inflation, interest and unemployment rate of Pakistan: Revisited. Munich Personal RePEc Archive, 1 -16. Retrieved from https://mpra.ub.uni-muenchen.de/78101/

Babalola, A. I. (2013). Interest rate and unemployment nexus in Nigeria: An empirical analysis. International Journal of Research in Commerce, Economics and Management, 3(11), 42-45.

Bala, U., Ibrahim, A., \& Hadith, N. B. (2020). Impact of population growth, poverty and unemployment on economic growth. Asian Business Research Journal, 5, 48-54. https://doi.org/10.20448/journal.518.2020.5.48.54

Brown, S. P. A., \& Yücel, M. K. (2002). Energy prices and aggregate economic activity: An interpretive survey. The Quarterly Review of Economics and Finance, 42, 193-208.

Burakov, D. (2017). Oil price, economic growth and emigration: An empirical study of transmission channel. International Journal of Energy Economics and Policy, 7(1), 90-98.

Cantavella, M. (2020). Fluctuations of oil prices and gross domestic product in Spain. International Journal of Energy Economics and Policy, 10(2), 57-63. https://doi.org/10.32479/ijeep.8806

Davis, L. (2013). The economic cost of global fuel subsidies. Hass Energy Institute Working Paper, 247.

Dickey, D. A., \& Fuller, W.A. (1979). Distribution of the estimators for autoregressive time series with a unit root. Journal of the American Statistical Society, 75, 427-431.

Doğrul, H. G., \& Soytas, U. (2010). Relationship between oil prices, interest rate, and unemployment: Evidence from an emerging market. Energy Economics, 32, 1523-1523.

Ehikioya, B. I., Omankhanlen, A. E., Babajide, A. A., Osuma, G. O., \& Omodero, C. O. (2020). Oil price fluctuations and exchange rate in selected sub-Saharan Africa countries: A Vector error correction model approach. International Journal of Energy Economics and Policy, 10(6), 242-249. https://doi.org/10.32479/ijeep.9822

Elliot, G., Rothenberg, T. J., \& Stock, J. H. (1996). Efficient tests for an autoregressive unit root. Econometrica, 64, 813836.

Ezirim, A. C., Okeke, C. T., \& Ebiriga, O. T. (2010), Achieving vision 2020 in Nigeria: A review of the economic and market- oriented business reforms. Journal of Sustainable Development in Africa, 12(4), 78-10.

Gylych, J., Jbrin, A. A., Celik, B., \& Isik, A. (2020). The effect of oil price fluctuation on the economy of Nigeria. International Journal of Energy Economics and Policy, 10(5), 461-468. https://doi.org/10.32479/ijeep.9493

Haque, M. I., \& Khan, M. K. (2019). Role of oil production and government expenditure in improving human development index: Evidence from Saudi Arabia. International Journal of Energy Economics and Policy, 9(2), 251-256. https://doi.org/10.32479/ijeep.7404

Joo, Y. C., \& Sung, Y. P. (2017), Oil prices and stock markets: Does the effect of uncertainty change over time? Energy Economics, 61, 42-51.

Kyari, A. K. (2020). The impact of petroleum tax incentives on foreign direct investment inflow: Evidence from Nigeria. International Journal of Energy Economics and Policy, 10(4), 516-524. https://doi.org/10.32479/ijeep.9187 
Mahmood, Y., Rabia, B., \& Aslam, M. (2013). Trade-off between inflation, interest and unemployment rate of Pakistan: A cointegration analysis. Pakistan Journal of Commerce and Social Sciences, 7(3), 482-492.

Maijama'a, R., \& Musa, K. S. (2020). Crude oil price, urbanization and environmental pollution in Nigeria: Evidence from ARDL approach. Asian Journal of Economic Modelling, 8(4), 227-240. https://doi.org/10.18488/journal.8.2020.84.227.240

Maijama'a, R., Musa, K. S., Yakubu, M., \& Mohammed, N. (2019). Impact of population growth on unemployment in Nigeria: Dynamic OLS approach. Journal of Economics and Sustainable Development, 10(22), 79-89. https://doi.org/10.7176/JESD/10-22-09

Majidli, F., \& Guliyev, H. (2020). How oil price and exchange rate affect non-oil GDP of the oil-rich country-Azerbaijan? International Journal of Energy Economics and Policy, 10(5), 123-130. https://doi.org/10.32479/ijeep.9561

Millington, D. (2016). Low crude oil price and their impact on Canadian economy, Study No.156. Alberta: Canadian Energy Research Institute.

Muhdin, M. B. (2016): Determinants of youth unemployment of urban areas of Ethiopia. International Journal of Scientific and Research Publications, 6(5), 343-350.

Musa, K. S., \& Maijama'a, R. (2020). Causal relationship between renewable energy consumption and unemployment in Nigeria: Evidence from Toda and Yamamoto causality technique. Energy Economics Letters, 7(1), 46-60. https://doi.org/10.18488/journal.82.2020.71.46.60

Musa, K.S., Maijama'a, R., Muhammed, N., \& Usman, A. (2019). Crude oil price and exchange rate nexus: An ARDL Bound Approach. Open Access Library Journal, 7(6), 1-24. https://doi.org/10.4236/oalib.11060720

Musa, K. S., Maijama'a, R., Nasiru M., \& Sambo, H. A. (2019). Interest rate and inflation nexus: ARDL bound test approach. Journal of Economics and Sustainable Development, 10(20), 55-64. https://doi.org/10.7176/JESD/10-20-07

Musa, K. S., Maijama'a, R., Shaibu, H. U., \& Muhammad, A. (2019). Crude oil price and exchange rate on economic growth: ARDL Approach. Open Access Library Journal, 6(5), 1-16. https://doi.org/10.4236/oalib.1105930

Muthalib, A. A., Adam, P., Rostin, Saenong, Z., \& Suriadi, L. O. (2018). The influence of fuel prices and unemployment rate towards the poverty level in Indonesia. International Journal of Energy Economics and Policy, 8(3), 37-42.

Oduyemi, G., \& Owoeye, T. (2020). Oil price fluctuation and health outcomes in an oil exporting country: Evidence from Nigeria. International Journal of Energy Economics and Policy, 10(4), 212-220. https://doi.org/10.32479/ijeep.9266

OPEC. (2020). Organization of oil exporting countries crude oil prices, 1960-2020. Retrieved from https://www.statista.com/statistics/262858/change-in-opec-crude-oil-prices-since/1960/.

Papapetrou, E. (2001). Oil price shocks, stock market, economic activity and employment in Greece. Energy Economics, 23(5), 511-532. https://doi.org/10.1016/S0140-9883(01)00078-0

Pordan, I. (2013). The effects of whether on stock returns: A comparison between emerging and developed markets. Germany: Anchor Academic Publishing, Hamburg. Retreived from https://m.anchor-publishing.com/document/287377

Rumbia, W. A., Muthalib, A. A., Abbas, B., Adam, P., Millia, H., Saidi, L. O., \& Azis, M. I. (2020). Crude oil prices, household spending and economic growth in the ASEAN-4 region: An analysis of nonlinear panel autoregressive distributed lag. International Journal of Energy Economics and Policy, 10(4), $437-442$. https://doi.org/10.32479/ijeep.9293

Saidi, L. O., Aedy, H., Saranani, R. F., Osnawintang, A. P., \& Sani, L. O. A. (2020). Crude oil price and exchange rate: An analysis of the asymmetric effect and volatility using the non-linear autoregressive distributed lag and general autoregressive conditional heterochedasticity in mean models. International Journal of Energy Economics and Policy, 10(1), 104-108.

Sapuan, N. M., \& Roly, M. R. (2020). Oil abundance and human capital in Malaysia: A multivariate cointegration analysis. International Journal of Energy Economics and Policy, 10(3), 303-310. https://doi.org/10.32479/ijeep.8578

Siddig, K., Aguiar, A., Grethe, H., Minor, P., \& Walmmsley, T. (2014). Impacts of removing refined oil import subsidies in Nigeria on poverty. Energy Policy, 69, 165-178.

Toda, H. Y., \& Yamamoto, T. (1995). Statistical inference in vector autoregression with possibly integrated processes. Journal of Econometrics, 66(1), 225-250.

Wiryono, S. K., Sudrajad, O. Y., Prasetio, E. A., \& Setiawati, M. (2020). Do oil price shocks give impact on financial performance of manufacturing sectors in Indonesia? International Journal of Energy Economics and Policy, 10(5), 510514. https://doi.org/10.32479/ijeep.9808

World Development Indicators (2020). World Bank Database. Retrieved from https://data.worldbank.org/indicator 